\title{
Decrease in the Rate of Protein Synthesis by Polysomes from Cultured Fibroblasts of Patients and Carriers with Duchenne Muscular Dystrophy
}

\author{
M. BOULE, M. VANASSE ET L. BRAKIER-GINGRAS
}

SUMMARY: Polysomes extracted from cultured fibroblast cells isolated from patients with Duchenne muscular dystrophy (DMD), carriers of the disease, and normal controls were used for in vitro measurement of protein synthesis in a wheat germ extract system. It was observed that polysomes from patients and carriers (seven of

RESUME: Nous avons étudié l'activité de synthèse in vitro de polysomes de fibroblastes provenant de malades atteints de la dystrophie musculaire de Duchenne (DMD), de porteuses de la maladie et de contrôles. Le système acellulaire utilisé pour cette étude est un extrait de germe de blé. Nous avons ainsi examiné l'activité de synthèse des polysomes provenant de 7 malades, 7 each aged 17 years or older) exhibited a 3-fold and a 1.5-fold decrease in the rate of protein synthesis, respectively, as compared with controls. These results are discussed with a view to developing a sensitive and easily available assay for the detection of $D M D$ carriers.

porteuses et 7 contrôles (âgés de 17 ans et plus) et nous avons observé que cette activité était réduite d'un facteur 3 et 1.5 pour les malades et les porteuses respectivement, par comparaison avec les contrôles. Ces résultats sont discutés en vue de la possibilité de développer une méthode sensible et simple de détection des porteuses de la $D M D$.
From the - Département de Biochimie, Université de Montréal et Section de Neurologie, Hôpital SainteJustine Montréal, Québec, Canada.

Reprint requests to Dr. L. Brakier-Gingras, Département de Biochimié, Université de Montréal, H3C 3J7. Montréal, Québec, Canada.

Abbreviations: ATP, adenosine-5'-triphosphate; GTP, guanosine-5'-triphosphate; HEPES, 4-(2-hydroxyethyl)-1-piperazineethane-sulfonic acid; DMD, Duchenne muscular dystrophy.

Enzyme: creatine kinase (EC 2.7.3.2)

Definition: $1 \mathrm{~A}_{260}$ unit is the amount of material which would give an absorbance of 1.0 at $260 \mathrm{~nm}$ in a length path of $1 \mathrm{~cm}$ and a volume of $1.0 \mathrm{ml}$.

\section{INTRODUCTION}

Duchenne muscular dystrophy (DMD) is an X-linked inherited disease for which no effective treatment has been developed. Hence, the detection of carriers is important and is a problem which is not completely solved. The most widely used method for carrier detection consists of measuring the serum level of creatine phosphokinase (CPK) activity, which, although higher in most carriers, can detect only 60 to $70 \%$ of genetically proven carriers (Dubowitz, 1975; Roses et al., 1976). This has prompted many workers to search for alternate and more efficient tests. Other enzymatic activities have been examined in carriers and, more recently, structural and biochemical abnormalities have been observed in red blood cells (Roses et al., 1976; Solomons et al., 1977), but none of these tests has proven to be superior to the CPK assay (Lane et al., 1978; Seay et al., 1978; Smith and Thomson, 1977).

Abnormalities in the rate of protein synthesis in dystrophic muscles have been reported by several workers (Moncton and Nihei, 1969; Ionasescu et al., 1971, 1973; Ionasescu, 1975) and Ionasescu and his collaborators state they can use such abnormalities to detect $98 \%$ of the carriers (Ionasescu et al., 1976). Protein synthesis is a complex process which involves in addition to messenger RNA and ribosomes (the polysomes) transfer RNAs and the soluble factors (aminoacyl-tRNA synthetases, initiation, elongation, and termination factors) [reviewed in Lengyel, 1974].

The system devised by Ionasescu et al. to detect carriers is complex, requiring the isolation of polysomes 
and of soluble factors from muscles. In the present study, we have investigated the rate of protein synthesis using only polysomes extracted from fibroblasts of DMD patients and carriers. The soluble factors are supplied by an extract of wheat germ, therefore limiting the contribution of tested cells to polysomes. It will be shown that a significant decrease in the rate of protein synthesis with polysomes from DMD carriers and patients can be detected. These data are discussed in terms of the possibility of developing an easy, sensitive, and reliable assay for the detection of carriers.

\section{MATERIALS AND METHODS Subjects}

Skin biopsies were performed on 7 dystrophic patients, 7 definite carriers and 7 controls (aged between 17 and 35 years). The diagnosis of Duchenne dystrophy in the patients was based on clinical observations, high CPK level, electromyographic studies, and muscle biopsy. Definite carriers were, according to the definition of Dubowitz (1975), women with a high CPK level and one or more affected children, or with one affected brother and one or more affected children. Controls were healthy adults.

\section{Chemicals}

Eagle's Minimum Essential Medium (MEM) was purchased from Gibco (Grand Island Biological Company, New-York); fresh commercial wheat germ was obtained from General Mills, Chicago, Illinois; $\left[{ }^{14} \mathrm{C}\right]$ leucine (specific activity, $104 \mathrm{Ci} / \mathrm{mol}$ ) was from Schwarz-Mann, Orangeburg, New-York; Sephadex G-25 was from Pharmacia; Nonidet P-40 was from Particle Data Laboratories, Elmhurst, Illinois; materials and products for in vitro protein synthesis were obtained from Boehringer-Mannheim Corp; ribonuclease-free sucrose was from Schwarz-Mann.

\section{Skin fibroblast cultures.}

Skin specimens were cut into fragments and placed in Falcon dishes with Eagle's MEM supplemented with $20 \%$ fetal calf serum and antibiotics. The cultures were incubated at $37^{\circ} \mathrm{C}$ in a humidified atmosphere with 5\% $\mathrm{CO}_{2}$, and the culture medium was renewed twice weekly. Cells in the log phase of growth were recovered by centrifugation following trypsination with $0.025 \%$ trypsin.
Preparation of the S-30 fraction from the wheat germ lysate and isolation of polysomes from the fibroblast cells.

A $30,000 \mathrm{~g}$ supernatant (S-30) from wheat germ crude lysate was prepared following the method of Marcu and Dudock (1974). It was stored in aliquots at $-70^{\circ} \mathrm{C}$. Fibroblast cells were resuspended in 5 volumes of

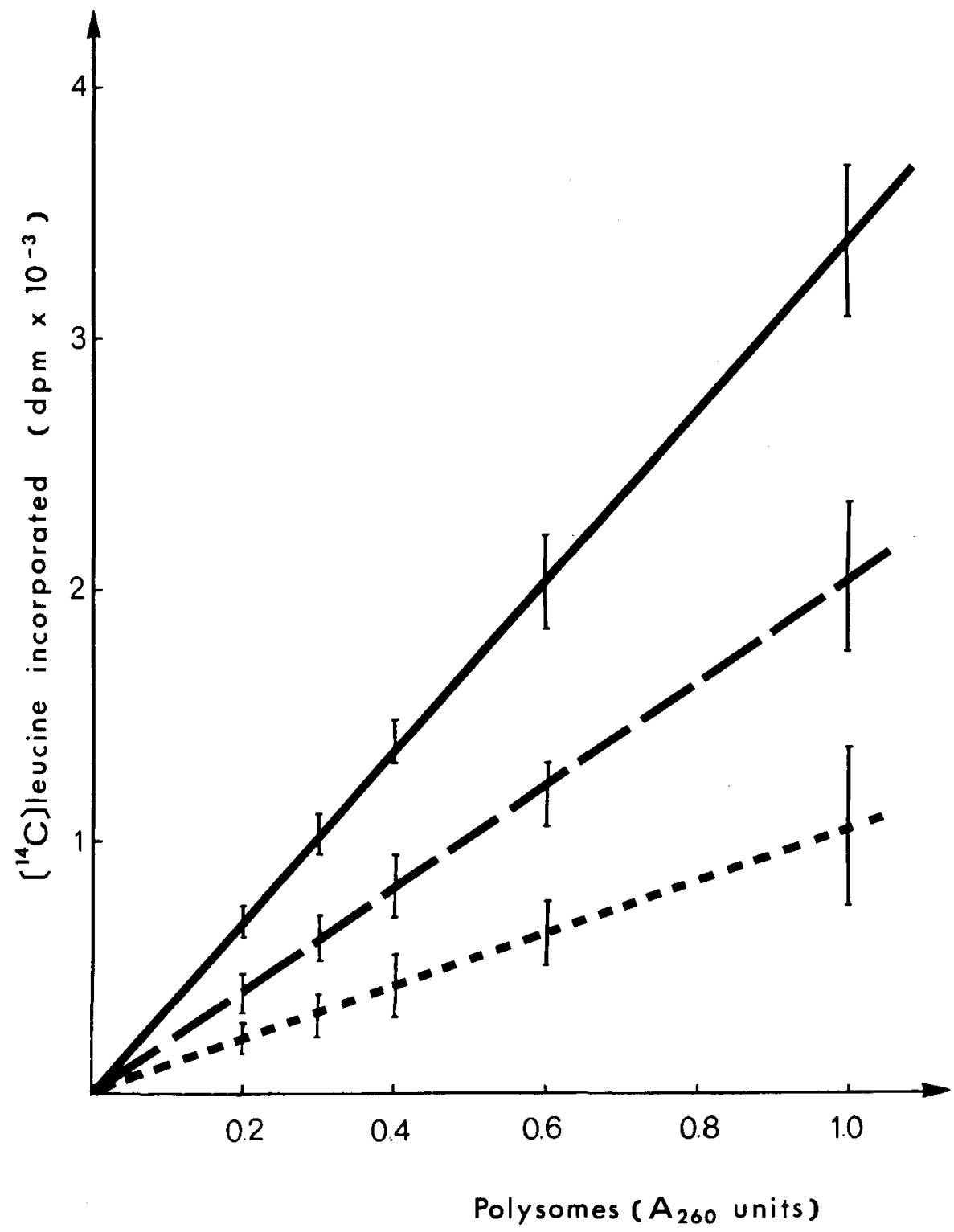

Figure $I-\left[{ }^{14} \mathrm{C}\right]$ leucine incorporation versus the amount of polysome. Polysomes were extracted from fibroblasts of DMD patients ( $\left.-C_{-}\right)$carriers $(--\longrightarrow)$ and controls (—). Each experimental point corresponds to an average of at least 3 experiments with different fibroblast cultures. Vertical bars indicate the standard deviation. The linear regression was determined by the least squares method. Assays were optimized for $\mathrm{pH}$ and concentration of magnesium and potassium ions. 
buffer A $[200 \mathrm{mM}$ Tris-acetate ( $\mathrm{pH}$ 8.5), $50 \mathrm{mM} \mathrm{KC1}, 10 \mathrm{mM}$ magnesium acetate, $4 \mathrm{mM} \beta$-mercaptoethanol] containing $1.5 \%$ Nonidet $\mathrm{P}-40$, and homogenized. The homogenate was centrifuged for $10 \mathrm{~min}$ at $10,000 \mathrm{~g}$ and the supernatant was layered over 1.5 $M$ sucrose in buffer A $(5 \mathrm{ml}$ of supernatant over $1.5 \mathrm{ml}$ sucrose cushion) and centrifuged at $105,000 \mathrm{~g}$ for $90 \mathrm{~min}$ in a Beckman type $50 \mathrm{Ti}$ rotor. The pellet which contained the polysomes was resuspended in buffer $B[10 \mathrm{mM}$ Tris-acetate (pH 7.6), $20 \mathrm{mM} \mathrm{KCl,}$ $\mathrm{mM}$ magnesium acetate, $4 \mathrm{mM} \beta$ mercaptoethanol] and stored at $-70^{\circ} \mathrm{C}$. The concentration of polysomes was estimated from the measurement of the optical density at $260 \mathrm{~nm}$ [ $1 \mathrm{~A}_{260}$ unit is $80 \mu \mathrm{g}$ or 16 pmoles (Tashiro and Yphantis, 1965; Schreier and Staehelin, 1973)].

\section{Protein synthesizing system.}

Protein synthesis was carried out in a reaction volume of $50 \mu \mathrm{l}$, containing: ATP, $1.33 \mathrm{mM}$; GTP, $0.25 \mathrm{mM}$; creatine phosphate, $15 \mathrm{mM}$; creatine phosphokinase, $40 \mu \mathrm{g} / \mathrm{ml}$; HEPES buffer (pH 7.4), $15 \mathrm{mM}$; dithiothreitol, $2 \mathrm{mM} ;\left[{ }^{12} \mathrm{C}\right]$ aminoacids - leucine, $0.02 \mathrm{mM} ;\left[{ }^{14} \mathrm{C}\right]$ leucine $(104 \mathrm{Ci} / \mathrm{mol})$, $0.02 \mathrm{mM}$; $\mathrm{KCl}, 80 \mathrm{mM}$; magnesium acetate, $3 \mathrm{mM}$; S-30 from wheat germ, $1 \mathrm{~A}_{260}$ unit; polysomes, from 0.1 to 1.0 $A_{260}$ unit.

The reaction was carried out at $30^{\circ} \mathrm{C}$ for $60 \mathrm{~min}$ and was stopped by addition of 5\% trichloroacetic acid. Samples were filtered through Whatman GF/A glass filters which were dried, and the radioactivity deter- mined in a Tri-Carb liquid scintillation spectrometer in a toluene-based scintillation fluid. The counting efficiency was $80 \%$.

\section{RESULTS AND DISCUSSION}

Fig. 1 shows the $\left[{ }^{14} \mathrm{C}\right]$ leucine incorporation into trichloroacetic acid precipitable material as a function of the amount of polysomes obtained from DMD patients, carriers, and controls. Results are also expressed as the $\left[{ }^{14} \mathrm{C}\right]$ leucine incorporation per $A_{260}$ unit of polysome (Table 1). It is clear that there are marked differences in the rate of protein synthesis between polysomes isolated from DMD patients, carriers, and normal individuals. Polysomes from DMD patients exhibit a 3-fold decrease in protein synthesis, while polysomes from carriers are 1.5-fold less active than controls.

These results may seem at variance with those of Ionasescu et al., (1971, 1973) who observed an increase in protein synthesis with DMD patients and carriers. However, it should be pointed out that their assay system was different from ours. Their reaction mixture contained polysomes as well as the soluble factors from the tested cells. Contradictory results were also obtained in the case of dystrophic animals. Indeed, increases as well as decreases in the rate of protein synthesis have been reported (see for example Weinstock and Markiewicz, 1973; Batelle and Florini, 1973; Bester and Gevers, 1973; Petryshyn and Nicholls, 1976). It is not inferred here that defects other than in polysomes are not present in fibroblasts from DMD patients and carriers, but our system of investigation focuses on polysomes.

A relationship between the abnormalities at the level of protein synthesis observed in this study and the primary defect in DMD is not clear. The pathogenesis of the disease is not completely understood although it seems to involve a membrane defect (Rowland, 1976). An interesting observation from these studies is that the genetic lesion does not appear to be restricted to muscles but is also expressed in fibroblasts. Because skin biopsies are easily obtained, it is then obvious that fibroblasts would constitute a suitable material for investigations of DMD. The immediate aim of our research is to develop an improved method for the detection of DMD carriers. In this context, our assay system has revealed clear-cut differences between DMD patients, carriers, and controls. The assay is relatively easy to perform and reproducible. Although it appears to be promising, we realize that a larger number of carriers need to be examined before any definite conclusion can be drawn.

\section{ACK NOWLEDGEMENTS}

We express our appreciation to Drs. R. Lafontaine, K. Majumdar, S.B. Melançon, K. Savard, and G. Shore for their numerous advices and their interest in this work. We thank B. Grenier for skilful technical assistance and $\mathrm{S}$. Tawadros for taking part in this work as a summer student. This investigation was supported by a grant of the Muscular Dystrophy Association of Canada. M. Boulé acknowledges support of a studentship from the Muscular Dystrophy Association of Canada.

TABLE I

Incorporation of $\left[{ }^{14} \mathrm{C}\right]$ Leucine per $A_{260}$ Unit of Polysome

\begin{tabular}{cc}
\hline Origin of Polysomes & $\begin{array}{c}\text { Incorporation } \\
\text { (dpm) }\end{array}$ \\
\hline Controls (7) & $3400 \pm 300$ \\
Carriers (7) & $2040 \pm 300$ \\
Patients (7) & $1060 \pm 300$ \\
\hline
\end{tabular}

\footnotetext{
The stimulation in incorporation over endogenous background was about 10-fold. Data correspond to patients, carriers, and controls aged between 17 and 35 years and we did not observe any age-dependence in this range. Incorporation of $\left[{ }^{14} \mathrm{C}\right]$ leucine with polysomes from carriers and patients is significantly different from controls at $P$ values $<0.01$.
}

\section{REFERENCES}

BATELLE, B.A. and FLORINI, J.R. (1973). Protein synthesis in chicken muscular dystrophy. Biochemistry, 12, 635-643.

BESTER, A.J. and GEVERS, W. (1973). Cellfree protein synthesis in heart and skeletal muscles from polymyopathic hamsters. Biochem. J. 132, 193-201.

DUBOWITZ, V. (1975). Carrier detection and genetic counseling in Duchenne dystrophy. Dev. Med. Child. Neur. 17, 352-356.

IONASESCU, V., ZELLWEGER, H. and CONWAY, T.W. (1971). A new approach for carrier detection in Duchenne muscular dystrophy. Protein synthesis of muscle polyribosomes in vitro. Neurology, 21, 703709. 
IONASESCU, V. ZELLWEGER, H., SHIRK, P. and CONWAY, T.W. (1973). Identification of carriers of Duchenne muscular dystrophy by muscle protein synthesis. Neurology, 23, 497-502.

IONASESCU, V. (1975). Distinction between Duchenne and other muscular dystrophies by ribosomal protein synthesis, J. Med. Genet. 12, 49-54.

IONASESCU, V., ZELLWEGER, $\mathrm{H}$. and BURMEISTER, L. (1976). Detection of carriers and genetic counseling in Duchenne muscular dystrophy by ribosomal protein synthesis. Acta Neurol. Scand. 54, 442-452.

LANE, R.J.M., MASKREY, P., NICHOLSON, G.A., SIDDIQUI, P.Q.R., TAKAHASHI, K., NICHOLSON, M., GASCOIGNE, P., PENNINGTON, R.J.T., GARDNERMEDWIN, D. and WALTON, J.N. (1978). An evaluation of some carrier detection techniques in Duchenne muscular dystrophy. Abstract 488, IVth. International Congress on Neuromuscular Diseases.

LENGYEL, P. (1974). The process of translation: a bird's eye view, in Ribosomes, Nomura, M., Tissières, A. and Lengyel, P., eds., pp 13-52, Cold Spring Harbor Laboratory.
MARCU, K. and DUDOCK, B. (1974). Characterization of a highly efficient protein synthesizing system derived from commercial wheat germ. Nucleic Acids Res. 11, 1385-1397.

MONCKTON, G. and NIHEI, T. (1969). A correlation of histology and amino acid incorporation studies in Duchenne muscular dystrophy. Neurology, 19, 415-418.

PETRYSHYN, R. and NICHOLLS, D.M. (1976). Protein synthesis in dystrophic muscle; activity of the $\mathrm{pH} 5$ supernatant fraction of muscle in dystrophic mice. Biochim. Biophys. Acta, 435, 391-404.

ROSES, A.D., ROSES, M.J., MILLER, S.E., HULL, K.L. and APPEL, S.H. (1976). Carrier detection in Duchenne muscular dystrophy. New Engl. J. Med. 294, 193-198.

ROWLAND, L.P. (1976). Pathogenesis of muscular dystrophies. Arch. Neurol. 33, 315-321.

SCHREIER, M.H. and STAEHELIN, T. (1973). Initiation of mammalian protein synthesis: the importance of ribosome and initiation factor quality for the efficiency of in vitro systems. J. Mol. Biol. 73, 329-349.
SEAY, A.R., ZITER, F.A., WU, L.H. and WU, J.T. (1978). Serum creatine phosphokinase and pyruvate kinase in neuromuscular disorders and Duchenne dystrophy carriers. Neurology, 28, 1047-1050.

SMITH, I. and THOMSON, W.H.S. (1977). Carrier detection in $\mathrm{X}$-linked recessive (Duchenne) muscular dystrophy: pyruvate kinase isoenzymes and creatine phosphokinase in serum and blood cells. Clin. Chim. Acta 78, 439-451.

SOLOMONS, C.C., RINGEL, S.P., NWUKE, E.I. and SUGA, H. (1977). Abnormal adenine metabolism of erythrocytes in Duchenne and myotonic muscular dystrophy. Nature, 268, 55-56.

TASHIRO, Y. and YPHANTIS, D.A. (1965) Molecular weights of hepatic ribosomes and their subunits. J. Mol. Biol. 11, 174-186.

WEINSTOCK, I.M. and MARKIEWICZ, L. (1974). Muscle protein synthesis during development of the normal and dystrophic chicken. Biochim, Biophys. Acta, 374, 197. 206. 